Report Series No. 93-06, North York: North York Community Health Promotion Research Unit, 1993.

3. Allison K, Rootman I. Scientific rigor and community participation in health promotion research. Health Prom Int 1996;11(4):333-40.

4. Boutilier M, Badgley RF, Sage L, Marz C. Action research: A model to assess and enhance collaboration in public health, In: Thurston WE, Sieppert JD, Wiebe VJ (Eds.), Doing Health Promotion Research: The Science of Action. Calgary: University of Calgary Health Promotion Research Group, 1998.

5. Park P, Brydon-Miller M, Hall B, Jackson T. (Eds.). Voices of Change: Participatory Research in the United States and Canada. Toronto: OISE Press, 1993.

6. World Health Organization. Ottawa Charter for Health Promotion. Health Prom 1986;1(4):iii-v.

7. World Health Organization, Health for All, Copenhagen: WHO Regional Office for Europe, undated.

8. Epp J. Achieving Health for All: A Framework for Health Promotion. Ottawa: Health and Welfare, Canada, 1986.
9. Ontario Health Review Panel. Toward a Shared Direction for Health in Ontario. Toronto: Ontario Ministry of Health, 1987.

10. Minister's Advisory Group on Health Promotion. Health Promotion Matters in Ontario. Toronto: Ministry of Health, 1987.

11. Ontario Ministry of Health. Mandatory Health Programs and Services Guidelines. Toronto: $\mathrm{MOH}, 1989$.

12. Spasoff RA. A new approach to health promotion in Ontario. Health Promo Int 1992;7(2):129-33.

13. Ministry of Health Ontario. Working Document: Goals and Strategic Priorities, Ministry of Health. Toronto: Ministry of Health, January 1992.

14. Pascal CE. So you want to be my partner?: Some Notes on Partnership and Democratic Administration. Ontario: Premier's Council on Health Well-being and Social Justice, August 1991.

15. Premier's Council on Health, Well-being, and Social Justice. Yours, Mine and Ours: Ontario's Children and Youth: Phase One. Ontario: Premier's Council on Health, Well-being, and Social Justice, May 1994.
16. Boutilier M, Tobin S, Poland B, et al. Community Action and Public Health in Ontario: Reflections on a Qualitative, Multiple Case Study. Annual Conference of the Ontario Public Health Association, Toronto, November 15, 1996.

17. Boutilier M, Tobin S, Badgley RF, et al. Strategies in Community Action: Challenges and opportunities in Ontario. Annual Conference of the Canadian Public Health Association, Montreal, June 8, 1997

18. Poland B, Boutilier M, Tobin S, Badgley RF. The policy context for community development practice in public health: Evidence and implications from a Canadian qualitative multiple case study. J Public Health Policy.

19. Ontario Progressive Conservative Party. The Common Sense Revolution. Toronto: Ontario PC Party, 1995.

20. Jackson S. Written communication. Toronto: August 23, 1999.

21. De Leeuw E. Health policy, epidemiology and power: The interest web. Health Prom Int 1993;8(1):49-52.

\title{
Tobacco Industry Litigation and the Role of Government: A Public Health Perspective
}

\author{
Roberta Ferrence, PhD, ${ }^{1-3}$ Mary Jane Ashley, $M D,{ }^{1,3}$ \\ Joanna Cohen, PhD, ${ }^{1,3}$ Thomas Stephens, PhD ${ }^{1,3,4}$
}

We welcome this opportunity to comment on issues raised by our colleagues on the role of government in tobacco industry litigation. Fischer and Rehm (pp. 7-8, January/February 2001 issue) argue that it is hypocritical and may be inappropriate for the state to initiate litigation against the tobacco industry. We propose a different 'tobacco logic': starting to smoke is rarely the rational act of informed adults, tobacco is not comparable to other consumer products, the government does not profit from tobacco, and litigation is a key component of a comprehensive tobacco control strategy.

Tobacco is a highly addictive drug, which most smokers begin to use as children or adolescents. ${ }^{1}$ Most beginners believe they will not become addicted, yet many quickly do, ${ }^{2,3}$ and most who continue to smoke as adults are addicted. While we agree that the public is much better informed than it used to be about the dan- gers of smoking, we do not believe that most beginners are well informed about their own susceptibility to addiction.

No other consumer product (including vehicles, and certainly skis) kills half its long-term users, when used exactly as intended by the manufacturer. Just as industrial polluters are held responsible for the environmental damage they cause, tobacco manufacturers should be held responsible for the societal damage they knowingly cause, as manifested by at least 34,000 deaths, 194,000 hospital admissions, and $\$ 2.68$ billion in health care costs annually in Canada. 4,5

The misperception persists that governments profit from tobacco. In fact, conservative estimates of health costs are at least double provincial government tax revenues for tobacco. ${ }^{6}$

Litigation can be viewed as one reinforcing component of a comprehensive strate- gy to control tobacco use that could provide a number of benefits to public health. ${ }^{6}$ Successful litigation would likely lead to price increases by the industry to cover costs, ultimately resulting in reduced smoking and health care costs. Litigation is a public health measure that, like water treatment, is not generally practicable at the individual level.

Tobacco litigation also helps to denormalize the tobacco industry and its products, a key element (along with prevention, protection, and cessation) in Canada's National Tobacco Strategy. One of the major benefits of litigation in the United States has been the release of industry documents. Through the discovery process, we have learned about industry efforts to mislead the public, suppress research, and target youth and potential quitters.

Although the federal government and several provincial health ministries have made significant advances in tobacco control - including bans on advertising and promotion, protection from second-hand smoke, and graphic health warnings - we agree with Fischer and Rehm that other actions by government are not only warranted, but are urgently needed. The most critical of these, tax increases, can only be undertaken by government. The tax increases that were implemented in the 1980s resulted in a substantial decrease in the prevalence and level of smoking, particularly among youth. The illegal activities ... see Tobacco, page 112 
collected cohort, and at the time of the initial interview, women had significant incentives to be very open about their smoking habits. Also, assessment of changes in the number of reported cigarettes was possible.

A potential limitation of this study is generalizability. This research examined differences in reports relative to an initial reported value. Reliability of the initial report, and the extent of subsequent underreporting may differ between populations. Patients attending the MotheRisk program are highly motivated. It is assumed that the majority of these women provide complete and accurate information, in order to receive a more accurate risk assessment. In a population with no incentive for accurate reporting, the initial report could be less reliable. The extent of underreporting occurring after fetal distress may depend on a number of variables. Maternal guilt may result in an attempt to conceal behaviour, or may encourage complete divulgence. With our data, some of the incentives for maternal truthfulness may be lost postpartum, and it is unknown whether the postpartum report in our study population would be more or less reliable than a report in another population.

The results of this study reinforce the need to obtain biological markers of expo- sures during pregnancy. However, while biological markers can help distinguish smokers from nonsmokers, they may not be adequate for the detection of changes in consumption, as nicotine undergoes pharmacokinetic changes during pregnancy. ${ }^{15}$

Further studies in the area of underreporting should be undertaken to determine if there is some predictive value that can be gained from these results. Many studies categorize smoking behaviour as "light" versus "heavy", based on a value of 10 or more cigarettes per day. Four cigarettes per day could indeed affect that categorization and bias study results. If there is a consistent pattern of underreporting or determinants of underreporting, this would be important information in an attempt to improve the understanding of the maternal fetal toxicology of tobacco smoke.

\section{REFERENCES}

1. Jedrychowski W, Whyatt RM, Cooper TB, et al. Exposure misclassification error in studies on prenatal effects of tobacco smoking in pregnancy and the birth weight of children. J Exposure Analysis \& Environment Epidemiol 1998;8(3):347-57.

2. Klebanoff MA, Levine RJ, Clemens JD, et al. Serum cotinine concentration and self-reported smoking during pregnancy. Am J Epidemiol 1998;148(3):259-62.

3. Murray RP, Connett JE, Lauger GG, Voelker HT. Error in smoking measures: Effects of intervention on relations of cotinine and carbon monoxide to self-reported smoking. The Lung Health Study Research Group. Am J Public Health 1993;83(9):1251-57.
4. Walsh RA, Redman S, Adamson L. The accuracy of self-report of smoking status in pregnant women. Addictive Behav 1996;21(5):675-79.

5. Welte JW, Russell M. Influence of socially desirable responding in a study of stress and substance abuse. Alcoholism, Clinical \& Experimental Res 1993;17(4):758-61.

6. DiFranza JR, Lew RA. Effect of maternal cigarette smoking on pregnancy complications and sudden infant death syndrome. J Fam Practice 1995;40(4):385-94.

7. Walsh RA. Effects of maternal smoking on adverse pregnancy outcomes: Examination of the criteria of causation. Human Biology 1994;66(6):1059-92.

8. Haslam C, Draper ES, Goyder E. The pregnant smoker: A preliminary investigation of the social and psychological influences. I Public Health Med 1997;19(2):187-92.

9. Hill LM. Diagnosis and management of fetal distress. Mayo Clinic Proceedings 1979;54(12):78493.

10. Parer JT, Livingston EG. What is fetal distress? Am J Obstet Gynecol 1990;162(6):1421-25.

11. Mead M. The diagnosis of foetal distress: a challenge to midwives. J Adv Nurs 1996;23(5):97583.

12. Gilstrap L, Leveno KJ, Burris J, et al. Diagnosis of birth asphyxia on the basis of fetal $\mathrm{pH}$, Apgar score, and newborn cerebral dysfunction. Am J Obstet Gynecol 1989;161:825-30.

13. Feldman Y, Koren G, Mattice K, et al. Determinants of recall and recall bias in studying drug and chemical exposure in pregnancy. Teratology 1989;40(1):37-45.

14. Neutra RR, Swan SH, Hertz-Picciotto J, et al. Potential sources of bias and confounding in environmental epidemiologic studies of pregnancy outcomes. Epidemiology 1992;3(2):134-42.

15. Seaton MJ, Vesell ES. Variables affecting nicotine metabolism. Pharmacology \& Therapeutics 1993;60(3):461-500.

Received: December 1, 1999

Accepted: September 7, 2000

\section{Tobacco, from page 89}

of the tobacco industry in orchestrating the smuggling that ensued have now been brought to light. Lack of progress on cigarette taxes and other key tobacco control measures, such as increased restrictions on smoking in public places and workplaces, is due to industry lobbying, lack of public concern, political ideology, and other political factors.

While the role of the state in public health and some of the concerns raised by Fischer and Rehm are worthy of further debate, we hope that such debate will not delay the implementation of measures that are known to be effective. Litigation can play an important role in holding the tobacco industry accountable for its contribution to the continuing epidemic of tobacco-related disease and death.

\section{The opinions expressed in this article are those of the authors and not of their respective institutions.}

\section{REFERENCES}

1. Hobbs FM, Pickett W, Ferrence RG, et al. Youth smoking in Ontario 1981-1997: A cause for concern. Can I Public Health 1999;90:80-82.

2. DiFranza JR, Rigotti NA, McNeill AD, et al. Initial symptoms of nicotine dependence in adolescents. Tobacco Control 2000;9:313-19.

3. Colby SM, Tiffany ST, Shiffman S, Niaura RS. Are adolescent smokers dependent on nicotine? A review of the evidence. Drug and Alcohol Dependence 2000;59 (Suppl 1):S83-S95.

4. Single E, Rehm J, Robson L, Truong MV. The relative risks and etiologic fractions of different causes of death and disease attributable to alcohol, tobacco and illicit drug use in Canada. CMAJ 2000;162:1669-75.

5. Single E, Robson L, Xie X, Rehm J. The economic costs of alcohol, tobacco and illicit drugs in Canada, 2000. Addiction 1998;93:991-1006.

6. Ashley MJ, Boadway $\mathrm{T}$, Cameron R, et al. Actions will speak louder than words: Getting serious about tobacco control in Ontario. A Report to the Minister of Health from her Expert Panel on the Renewal of the Ontario Tobacco Strategy. /Les actes sont plus éloquents que les mots : un plan d'attaque au tabagisme en Ontario. Rapport présenté à la ministre de la santé par son comité d'experts sur la relance de la stratégie antitabac de l'Ontario. Toronto, Canada: Expert Panel on the Renewal of the Ontario Tobacco Strategy: February 1999. ISBN 0-9686913-0-7 (http:www.camh.net/otru). 